\title{
火災統計資料に基づく延焼火災の特性 \\ 全国の延焼火災の傾向及び政令指定都市と東京23区の延焼火災件数と焼損床面積の分析 \\ CHARACTERISTICS OF FIRE SPREAD BASED ON THE FIRE STATISTICS MATERIAL
}

National trends of the fire spread and the analysis of fire spread cases and burnout floor area in Government-decreed cities and Tokyo's 23 wards

松 浦郁実*

\section{IkUmi MATSUURA}

\begin{abstract}
About 60,000 fires occur per year in Japan. Of them, over 30,000 cases were building fires. And burnout floor area is about $1,500,000 \mathrm{~m}^{2}$ per year. It is preferable to decrease the number and scale of fires. The purpose of this study is to analyze the behavior of fire and its spread. To analyze them, we used fire statistics which is available to the public. At the beginning, the object region was the whole of Japan. The second object is Government-decreed cities and Tokyo's 23 wards. We analyzed the rate which is the fire spread and non-fire spread. Next the research was the correlation between the burnout floor area of the fire origin building and the burnout floor area of buildings damaged by fire spread. The result shows that the Fire spreading is not a special thing as the side of the month. The burnout floor area increases as the number of burnt buildings increases. It is different from each region that the calculation guidelines about burnout floor area. There is poor correlation between the burnout floor area of the origin building and the burnout floor area of damaged buildings.
\end{abstract}

\section{Keywords: Fire statistics, Burnout floor area, Building fire} 火災統計，焼損床面積，建物火災

\section{1. はじめに}

消防白書によると，日本では建物火災，林野火災，車両火災，船 舶火災, 航空機火災, その他の火災を含めると毎年約 60,000 件の火 災が発生している，そのうち，30,000 件以上が建物火災であり，ま た, 図 1 は各年の火災の規模を示したものであるが，年間約

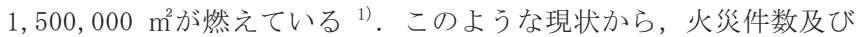
火災の規模が小さくなることが必要と考える. 理想は火災が無く, 火災の規模もない世の中である。しかし, 現実的には, 失火があり, さらに放火・放火の疑い（10,776 件/年：全火災の $20.6 \%)^{11}$ があ る。延焼火災について，火災統計を用いた既往の研究では，関沢・ 堀内 ${ }^{2)}$ が十大都市を対象にアンケート調査によって, 焼損面積（現 在の焼損床面積）の算定要領について地域ごとに解釈が異なること を考察している。佐藤ら ${ }^{3) 4}$ 徤物用途ごとに消防用設備が焼損床 面積の拡大に対して奏功しているか考察しており，また，火災の規 模を初期消火の失敗に特化し, 焼損床面積の大小を支配する要因に ついて分析している. 野崎・小林 ${ }^{5) 6}$ は, 非住宅系の建物について 小規模から大規模の火災のリスク評価について考察している，

また，延焼現象を対象とした既往の研究のうち，都市火災をテー マとした研究では, 亀井 ${ }^{7)}$ は, アンケートによって回収した資料を 基に都市別に延焼火災と不延焼火災と小火に分類し，延焼率と大火 率の関係を示している. 横井 ${ }^{8)}$ は, 延焼危険度という関数を定義し, 各府県の延焼危険度を算出している. 塚越・糸井川 ${ }^{9)}$ は, 都市防火
区画を取り囲む延焼遮断帯が，地震時に予想される市街地火災を遮 断し得るから゙うかを，火災条件，気象条件，延燒遮断帯の構成内容 に応じて判定するための評価手法を確立している. 村田 ${ }^{10)}$ は兵庫県 南部地震の被害を踏まえた地域の防災特性の評価を目的としており, 地震の被害地域特性に関わる要素との関連を抽出し, 整理, 分析し ている，高井ら ${ }^{11}$ は，消防隊員の活動記録と，消防局およびマスコ ミの映像記録等から解読可能な資料を収集, 解析し, 最も現実に近 い延焼動態について明らかにしようとしている．加藤ら ${ }^{12) 13) 15)}$ は， 一連の研究で, 現実の市街地に即したモデルに展開させている。齋 藤ら ${ }^{14)}$ は, 木造密集市街地の改善のために市街地の延焼性状を評価 する新たな指標の提案を行い, その妥当性と適用性を検証している. 村田ら ${ }^{16)}$ は耐火造・準耐火造建物の火災がどのような場合に周辺へ 延焼するのかを明らかにし，市街地の延焼危険性の評価に役立てる とともに延焼しにくい耐火造・準耐火造建物の設計指針のための知 見を得ることを目的としている，木村・系井川 ${ }^{17)}$ は，市街地の延焼 危険性に影響を与えている要因を把握し，今後市街地火災を低減さ せていく対策の一助になることを目的としている．シミュレーショ ン，モデルをテーマとした研究では，伊藤 ${ }^{18)}$ は延焼について計算式 を用いて，風向と延焼角に着目し延焼の期待值を考察している。田 村ら ${ }^{19)}$ は, 地震時の延焼拡大状沉を予測するシステムを開発した. 鈴木・吉田 ${ }^{20)}$ は, 確率論的な延焼拡大モデルを取り入れた火災シミ ユレーションモデルを提案し, 可燃物間の延焼過程を考慮した初期

\footnotetext{
$*$ 東京理科大学大学院 大学院生 $\cdot$ 修士 (工学)

Graduate Student, Tokyo University of Science, M. Eng.
} 
火災段階での発熱速度や煙層温度などの確率分布を求め, 可燃物に 対し, 防火対策を施したときの比較をしている. 出口ら ${ }^{211}$ は, 初期 火災時における火災の拡大に影響を及ぼすと考えられる可燃物特性 の中から, 可燃物配置の影響に着目寸るため, 同程度の燃焼性状を 有する同型のクリブを用いた延焼実験を行い，実験結果にもとづい て著者らの旧モデルを改良している，樋本・田中 ${ }^{22)}$ は，都市火災の 拡大を現象の物理的知見に基づいて定式化することで，より合理的 な延焼モデルを開発し，これまで著者らのモデル開発の内容を整理 し, その妥当性の検証をしている. 飯塚・青木 $\left.{ }^{23}\right)$ は, 建物構造や建 物用途の遷移構造を分析し, 将来延焼危険度が悪化する恐れのある 地域の示寸特徴を明らかにしている. 西野ら ${ }^{24)}$ は, 計算速度の速さ や計算に必要な情報量の節約を重視しつつ, 現象の物理的な知見に 基づいた準定常的な計算によって, 都市火災の延焼性状を簡易に予 測する手法を開発している. 延焼速度をテーマとした研究では, 保 野ら ${ }^{25) 26(27) 28) 29)}$ は建物火災の延焼速度式（ロジスティック曲線）に 関する決定係数法及び数值解析上の問題点について検討している.

以上, これまでの延焼火災について, 火災統計を用いた既往の研 究では, 建物から他の建物へと火が燃え移る延焼火災の特性につい ては未検討である。また, 延焼現象をテーマとした既往の研究では 多くの研究がされているが, 実験值や計算（シミュレーション, モ デル), 実際の大規模火災を取り上げているが，実際に発生した小さ い災から大きい火災の延焼火災に着目したものは見当たらない. 本稿での大きな特徵は火災統計資料を得て延焼火災の分析を試みる ことにある。同様の資料を利用した研究はあるが，延焼に特化した ものはない，このような，建物から他の建物へと火が燃え移る延焼 火災件数が減少することが望ましい。そこで，本稿では，行政情報 を利用し, 火災件数之焼損床面積を指標にして火元建物と被延焼建 物の関係を明らかにし, 延焼火災を減少させていきたい。 なお，本 稿で言う延焼火災の特性とは, 出火月, 出火時刻, 火災規模, 建物 構造を指している，延焼火災を扱う上で消防力も重要な要因である が，本稿で対象とする都市では，人口と消防署数の相関係数が 0.98 であり, 消防力は一定数以上の人口の各都市で同等と仮定できると 考える，その他，延焼火苂の特性として隣棟間隔や開口部の位置， 寸法が考えられるが, 本稿で利用寸る資料に記載されてなく, 他の 資料も調べたが, 上述した要素を整理されている資料はなかった. 外気風は火災統計資料に記載されているが, どの地点での測定か不 明瞭であったため考慮しない.

なお，本稿でいう延焼火災とは、出火した建物から，他の建物に 火災が拡大寸る火災をいう。この出火した建物を火元建物と呼び, 火元建物以外の火災によって被害を受けた他の建物すべてを被延焼 建物と呼ぶこととする.

\section{2. 研究方法}

本研究での延焼火災を減少させる仕組みは, まず近年の火災統計 より延焼火㷋の実態を示す. そして, 焼損床面積を指標に火元構造 別に分析し, 延焼火㷋件数の減少に有効な火元建物構造を示すこと で，延焼火災が減少すると考える．

検討項目として, 火災件数と焼損床面積を利用寸る. 火災件数及 び焼損床面積のみの分析では単純集計を示し, 火災件数及び焼損床 面積の両方を使う場合，期待値や割合を示す。
火災の規模の指標として, 焼損床面積と焼損表面積注 ${ }^{1)}$ があるが， 焼損床面積を利用する. 既往の研究 ${ }^{3) 455) 6}$ におおいて, 焼損床面積を 火災の規模の指標としており，また，火災統計において、年間の火 災の規模が焼損床面積の方が大きく（図 1)，延焼火災の特性の分析 をすることに適していると考えられるためである．火災の規模が大 きい方が延焼桩大している可能性が高く，被延焼建物の火災の規模 を比較すると, 焼損表面積より焼損床面積の方が約 4 倍多く, 結果 として, 焼損床面積の方が分析に適していると考える．また，焼損 床面積と焼損表面積では，定義（算定方法は注 1 参照）が異なるた め，本稿では焼損床面積のみを扱う。

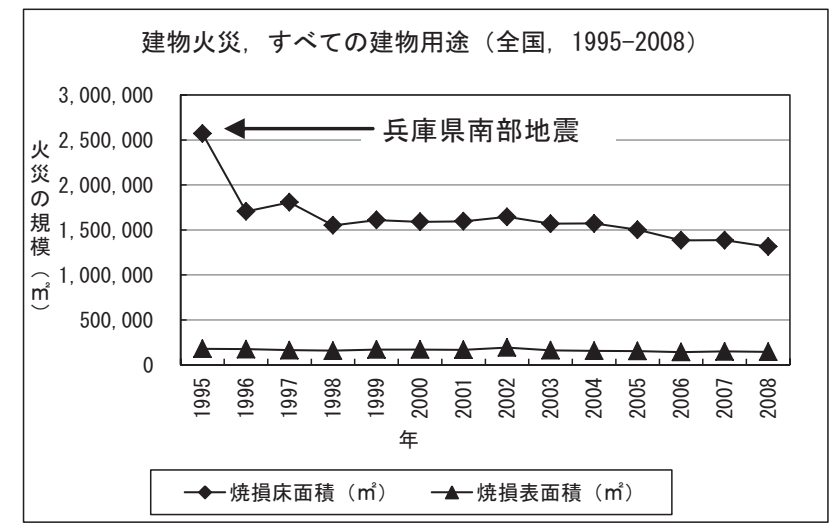

図 1 建物火災件数と焼損面積の経年変化（全国：1995-2008） ${ }^{11}$

これまで, 消防白書 ${ }^{1)}$ では延焼火災の火元建物と被延焼建物の火 災規模の関係を明らかにすることはできなかった。そこで，本研究 では，行政が保有している火災統計データである火災報告 ${ }^{30}$ 注2)を 利用する，火災報告を利用寸ることで，消防白書には掲載されてい ない情報から延焼火災の特性を明らかにできる可能性がある.また， 筆者が火災報告を入手した期間は，1995 年 1 月 1 日から 2008 年 12 月 31 日までの 14 年間分の電子データであり，火災報告によって得 られた火災件数は 826,278 件である.

次に，研究対象であるが，第一に日本全国を対象とし，全ての建 物火災と建物の延焼火災を比較して，延焼火災の特性を明らかにす る. そのために, 出火月, 出火時間, 火元建物用途別の火災件数の 割合，火元建物用途別の延焼火災の火災件数の割合，全ての火元用 途別建物火災の焼損床面積と火元用途別火災の被延焼建物の夕の焼 損床面積の検討，比較を行う．第二に政令指定都市及び東京 23 区を 対象とし, 延焼火災の特性を他の行政情報も利用して検討していく. ここでは対象建物を火元建物が戸建て住宅のものを対象とする，戸 建て住宅に限定した理由は後述する。また，延焼火災で延焼を受け た建物ではなく火元で建物用途を分類している理由は，火災報告に は, 被延焼建物の建物用途等の特性が記述されていないためである. 対象地域を政令指定都市及び東京 23 区に限定した理由は, 都市部と 地方部では都市構造及び消防力等の面で比較が困難であるが，都市 部（政令指定都市及び東京 23 区）では比較できると考える. 地方 部では, 母屋と納屋等の付属建物が同一敷地内にあると予想した. 検証の結果，14 年間（1995 年から 2008 年），ある村では，火元が戸 建て住宅の場合，全ての火災が延焼火災になり，罹災世帯が 1 世帯 の割合が高い（75.0\%以上）結果であった。よって，建物が密集し 
ていると思われる政令指定都市及び東京 23 区に着目した. なお, 政 令指定都市は以下の 17 都市である. 札幌市, 仙台市, さいたま市, 千葉市, 横浜市, 川崎市, 新潟市, 静岡市, 浜松市, 名古屋市, 京 都市, 大阪市, 堺市, 神戸市, 広島市, 北九州市, 福岡市 (2008 年 12 月 31 日時点).ただし, 各都市において, 当該期間中に市町村合 併がある場合は，合併前の市町村の火災件数も合算している．

なお, 本稿でいう相関係数とは, ピアソンの積率相関係数を指す. 相関係数は数值で $2 つ の$ 数量の関わり合いの度合いがわかる.ただ し, 相関係数は 2 変数の因果関係を説明寸るものではない. 本稿で の相関係数の使用目的は 2 変数のちらばり度合いであり, 因果関係 を求めることではない (出火月, 出火時間及び焼損床面積).よって, 本稿では，ピアソンの積率相関係数が必要と考え利用した.

\section{3. 日本の延焼火災}

\section{1 延焼火災件数の経年変化}

本節では，日本の建物火災の延焼火災件数の推移を概観する。ま ず，1995 年から 1997 年までの延焼火災件数について, データの除 外をする. デー夕の除外を行う理由は, 明らかに特異なデータ注 3) が入ることを避けるためである.火災報告のデータを整理した結果、 1995 年から 1997 年までは, 不自然な延焼火災件数の割合である. よって, 日本の延焼火災を調べる場合, 1995 年から 1997 年までの 日本全国のデータ（図 2 の網掛部）を除く

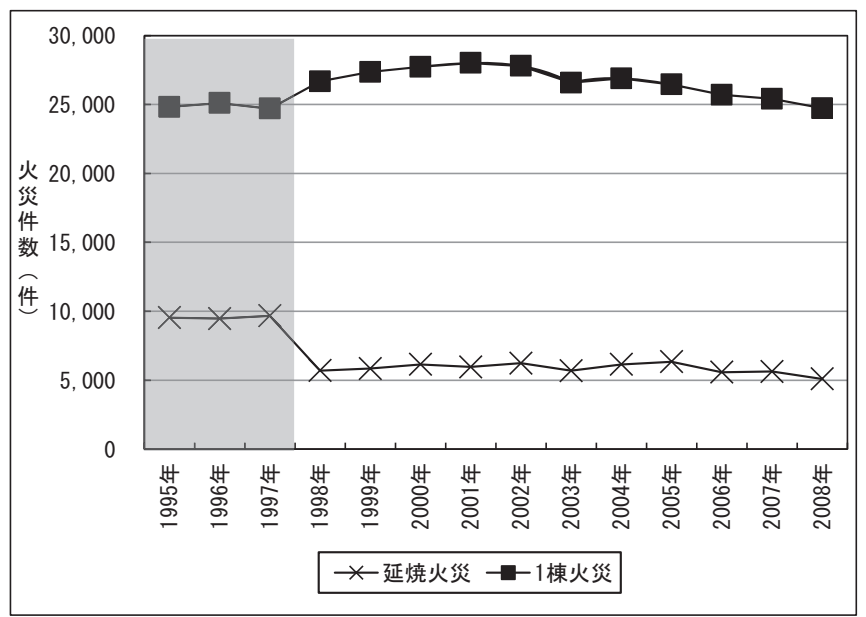

図 2 延焼火災と 1 棟火災件数の経年変化

図 2 より，1998 年以降の延焼火災は, 建物火災の全体の約 17\%で 推移している。一方，1棟火災は 1998 年から 2002 年にかけて増加 しているが, 傾向としては建物火災の全体の約 $83 \%$ を占めて推移し ている。

\section{2 出火月と出火時間}

次に, 延焼火災が全ての建物火災と出火月及び出火時間に違いが あるのかどうかを確認する。

第一に, 出火月であるが, 図 3 に示寸通り, 全ての建物火災の出 火件数と延焼火災のみの建物火災の出火月の分布は似ており, 相関 係数は 0.99 である. どちらの場合でも， 12 月から 3 月にかけて火 災件数が多く, 6 月から 9 月は出火件数が少ない。

第二に，出火時間であるが，図 4 に示す通り，全ての建物火災

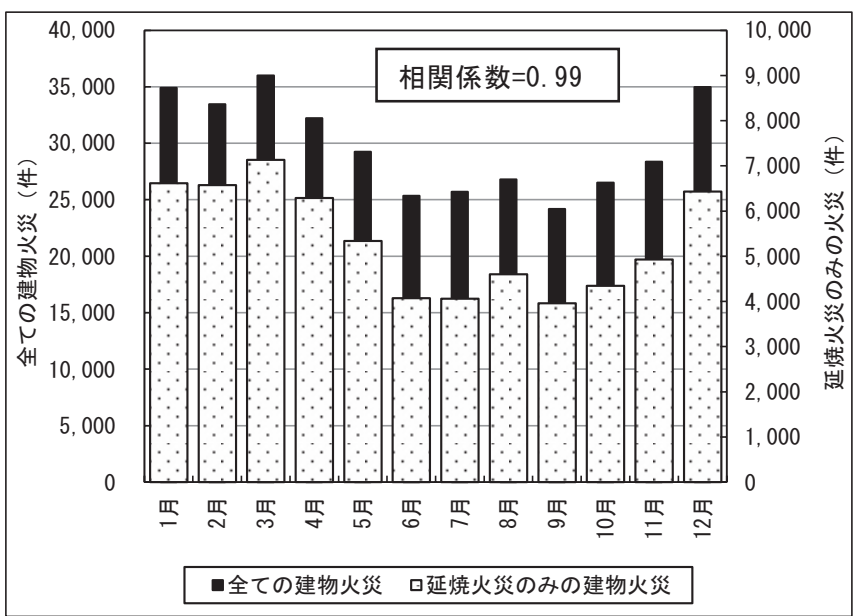

図 3 全ての建物火災と延焼火災のみの建物火災別の出火月 (1998 年-2008 年)

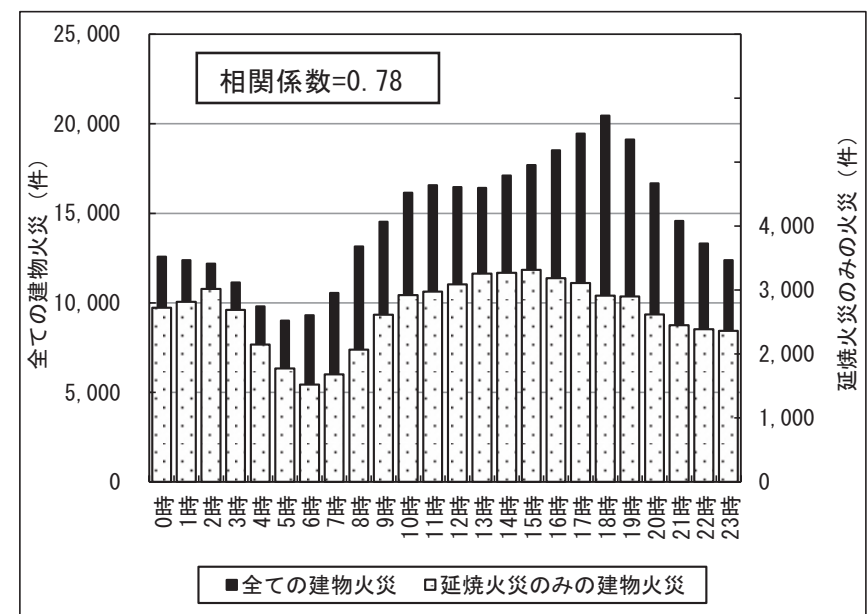

図 4 全ての建物火災と延焼火災のみの建物火災別の出火時間 (1998 年-2008 年)

と延焼のみの建物火災の出火時間の分布は出火月と比べると相関係 数は低くなり 0.78 である. どちらの分布も概数似た分布である.

全ての建物火災では夕方（18 時）にピークが見られるが，延焼火 災では 15 時がピークになり, 夕方には目立ったピークはない. 夕方 は, 調理時間帯と考えられ, 火災は発生するものの, 人間の活動時 間帯（起床時）なので，火災の早期発見につながり，延焼火災には 至りづらいと考えられる。 また，延焼火災のピークが 15 時という点 では，人間の活動時間帯（起床時）と思われるが，この時間帯は高 齢者及び障害をもつ者が 1 人になる可能性が高い時間帯とも考えら れる，その場合，火災の早期発見が遅れ延焼に繋がりやすいのでは ないだろうか. この時間帯は, 近隣住民の助け合いが大切な要素で あると考える。その結果, 火災の早期発見, 延焼拡大の防止に繋が るだろう。また, 延焼火災について, 深夜の 0 時から 3 時位も延焼 火災件数が多い。これは，放火が原因と思われる。消防白書によれ ば，放火が多い時間帯は 0 時から 4 時までである。そのような深夜 に放火された場合，火災の早期発見は難しいだろう。また，放火な ので，外壁及び外壁付近の可燃物に放火することが考えられる．外 壁付近に放火した場合，隣棟間隔が狭ければ，容易に延焼火災に発 
展するだろう。このような場合を考えて延焼火災件数減少に貢献す るには, 外壁周辺に可燃物を置かない, という対策をとることがで きると考える。

\section{3 火元建物用途別の火災件数}

これまでは, 全ての建物用途を含んだ火災件数の比較であったが、 具体的な火元建物用途別の特性を把握するため, 火元用途別注 4) の 火災件数の分布を示す.

まず，全ての建物用途別の火災件数であるが，1998 年から 2008 年までの 11 年間の建物火災のうち, 建物火災は 345,405 件であり (図 $5)$ ，延焼火災は 11 年間の建物火災のうち 60,495 件である（図 6).

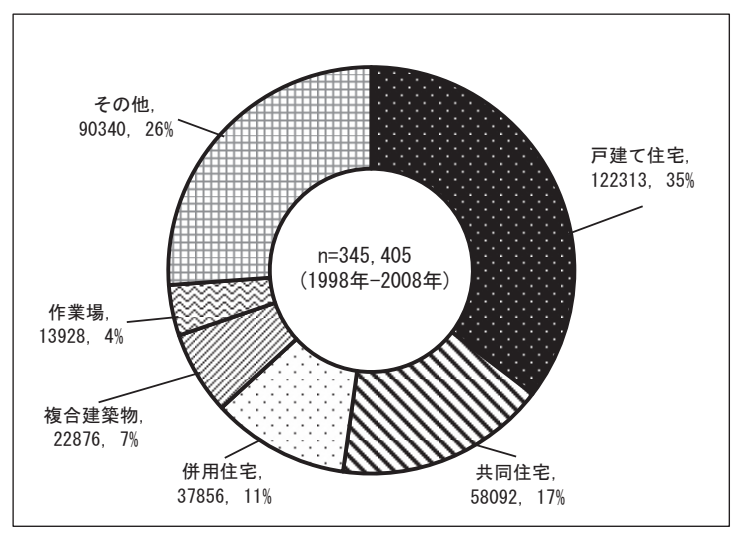

図 5 全ての建物火災の火元建物用途別火災件数の割合

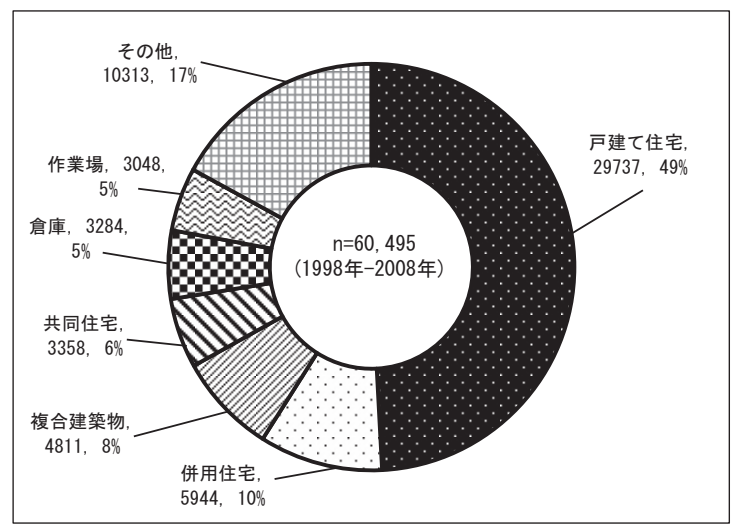

図 6 延焼火災のみの火元建物用途別火災件数の割合

全ての建物火災（図 5) では, 戸建て住宅は全体の 35\%であるが, 延焼火災（図 6）をみると $49 \%$ と，ほぼ半数の割合を占めている. この割合の増加は, 各建物用途で, 戸建て住宅が火を扱う時間が長 い建物用途であるからと考えられる。また，全ての建物火災では， 共同住宅が 2 位（17\%）であったが，延焼火災では，4位（6\%）に 減少している。これは, 戸建て住宅同様，火を扱う居住系建物用途 ではあるが，共同住宅の多くの建物構造が非木造（86.7\%）で，延 焼拡大しづらいからと思われる。一方, 全ての建物火災では, 上位 5 位に入らなかった倉庫が, 延焼火災では 5 位 (5\%) になっている. 倉庫の使用用途を考えると, 建物内に多くの収容可燃物が保管して あり，他の建物用途より火苂荷重が大きいと考えられる，そういっ た場合，倉庫内で火災が発生すれば，火災荷重大きいので，火災が 拡大し延焼する可能性が高くなるのではないだろうか.

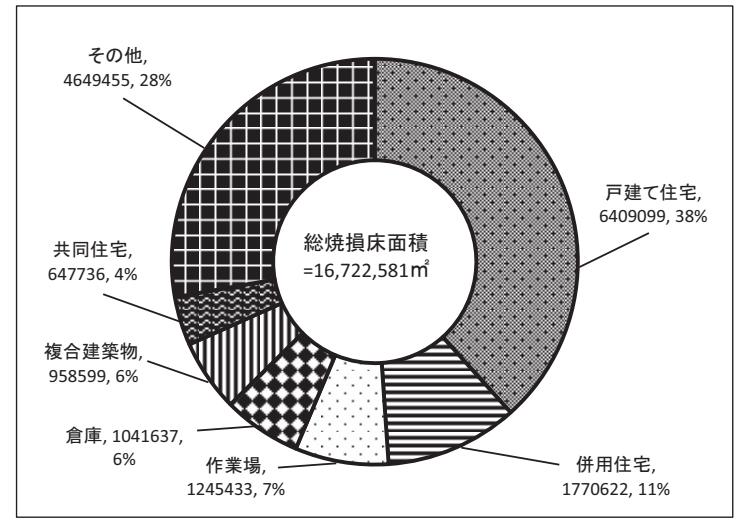

図 7 各建物用途から発生した火災の総焼損床面積 (1998-2008)

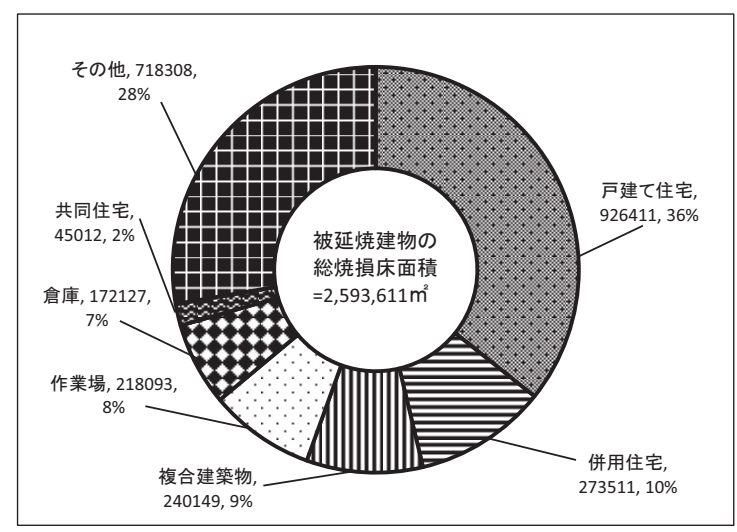

図 8 各火元建物から発生した火災の被延焼建物の総焼損床面積 (1998-2008)

次に, 図 7 及び図 8 より, 各建物用途から発生した火災の総焼損 床面積と被延焼建物の総焼損床面積の 1 位は戸建て住宅である。こ れは, 図 5 及び図 6 で示したように, 戸建て住宅の火災件数が多い ことも理由の一つであろう。また，図 7 と図 8 の戸建て住宅の割合 もほぼ同様というのも特徵の一つである. よって, 火元建物（戸建 て住宅）を除いても，焼損面積の多くを占めているのが戸建て住宅 ということが明らかとなった。また，複合建築物について，各建物 用途から発生した火災の総焼損床面積では 5 位（6\%）であったが， 被延焼建物の総焼損床面積では 3 位（9％）になっている。これは， 火元建物の火災規模より, 周囲の建物に影響を及ぼし延焼拡大に至 ると推測できる，共同住宅は先述したように，建物構造が非木造の 割合が高いことが，焼損床面積が小さい要因の一つであろう.

さらに，火災の規模の分布をみるため，火元が戸建て住宅の各焼 損棟数別の総焼損床面積の分布（図 9) と被延焼建物の各焼損棟数 別の総焼損床面積の分布を示す (図 10). この分析を行うことで, 各焼損棟数で火災の規模が異なる，もしくは同様である，というこ とを示すことを目的としている，なお，戸建て住宅に限定した理由 は, 火元建物別延焼火災件数（図 5), 火元建物別焼損床面積（図 8) が 1 位であるからである.今回, 焼損床面積の分布を示すにあたり, 1 棟焼損した場合 (火元建物の夕が焼損した場合)，2 棟焼損した場 合，3棟焼損した場合，4 棟焼損した場合， 5 棟焼損した場合，6 棟 焼損した場合、7 棟以上焼損した場合の 7 分類に分けてデータ整理 
を行った. 図 9 及び図 10 は火元用途が戸建て住宅である火災の焼損 床面積について, $0 \mathrm{~m}^{2}$ から 2,500 $\mathrm{m}^{2}$ までを抜粋した分布を示したも のである. また, 2 棟以上焼損した場合で, 焼損床面積が $0 \mathrm{~m}^{2}$ とな る延焼状況とは, 焼損床面積は四捨五入で算定するので, $0.5 \mathrm{~m}^{2}$ 未 満の延焼状況は焼損床面積 $0 \mathrm{~m}^{2}$ となる。 また, 外壁の一部のみの焼 損, 雨樋一部焼損等も延焼火災と報告されるが焼損床面積 $0 \mathrm{~m}^{2}$ とな る.このような, 軽微な火災が含まれているので図 9 及び図 10 に関 して焼損床面積 $0 \mathrm{~m}^{2}$ に着目した.

ただし, 図 9 及び図 10 の合計件数は図 5 の值と一致しない。これ は, 各用途で 0 棟火災という火災が記録されているためである. 図 9 より, 戸建て住宅に関して, 1 棟火災の場合, 焼損床面積が $0 \mathrm{~m}^{2}$ の 時に累積相対度数は約 0.7 であり, 多くの火災が焼損床面積 $0 \mathrm{~m}^{2}$ で ある. 次に, 2 棟火災の場合, 焼損床面積が $0 \mathrm{~m}^{2}$ の時, 累積相対度 数は 0.1 である. また, 3 棟火災から 6 棟火災までは分布形が似て いることが特徴であり, 燃える面積に大きな差はない. 分布が似て いるということは，延焼の状況に大きな変化がないと思われる。よ って，3 棟火災から 6 棟火災は軽微な延焼が多いと推測できる。ま た, 3 棟火災から 6 棟火災の約 8 割の火災の総焼損床面積が $300 \mathrm{~m}^{2}$ 以下という特徴がある。7 棟以上の火災になると多少ではあるが焼 損床面積が大きくなる傾向になることが読み取れる.

図 10 より, 被延焼建物に着目した場合, 2 棟火災の場合, 焼損床 面積が $0 \mathrm{~m}^{2}$ の時に累積相対度数が約 0.8 であり, 多くの 2 棟火災は

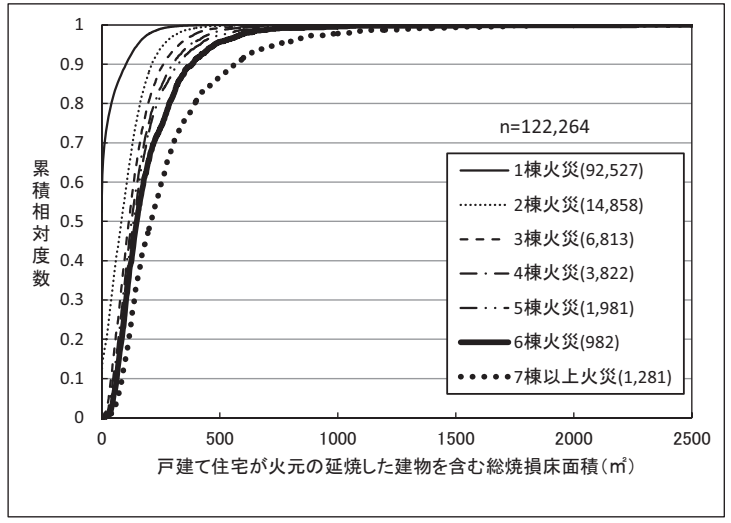

図 9 戸建て住宅からの火災の総焼損床面積の分布 (1998 年-2008 年)

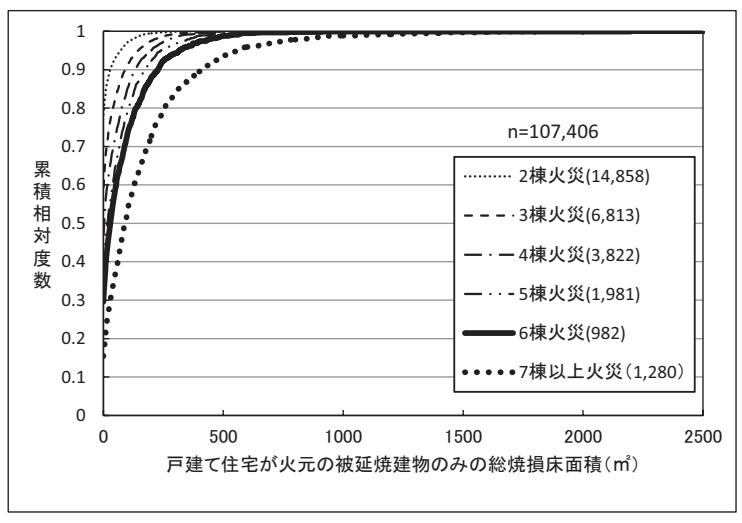

図 10 戸建て住宅が火元の被延焼建物の夕の総焼損床面積 (1998-2008)
燒損床面積が 0 m²である. 続いて, 3 棟火災，4 棟火災，5 棟火災， 6 棟火災と, 焼損床面積が $0 \mathrm{~m}^{2}$ の割合は減っていくものの, 累積相 対度数が約 0.4 以上である. 7 棟以上火災で累積相対度数が約 0.2 程度である。これらから，戸建て住宅が火元建物の場合，被延焼建 物への延焼拡大は小さいが，火災件数が多いため，図 8 の通り合計 すると火元建物が戸建て住宅の被延焼建物に多くの被害を出してい る.

\section{4. 政令指定都市及び東京 23 区の戸建て住宅からの延焼火災}

\section{1 戸建て住宅火災件数と建物棟数の相関}

本章においても，3 章と同様に 1998 年から 2008 年のデータを対 象とする.

3.3 節で示した通り, 戸建て住宅が火元建物用途別の延焼火災件 数で約半数を占めており，焼損床面積も大きい，そこで本節から戸 建て住宅に限定して分析を進めていく。ここでは，戸建て住宅火災 件数と戸建て住宅棟数の関係を確認する. 各都市の戸建て住宅の棟 数は, 公開されている行政情報の住宅・土地統計調査 ${ }^{31)}$ を利用した. 火災件数と戸建て住宅建物棟数の相関をみると, 相関が高くなって おり（相関係数=0.96）（図 11）, 都市部の戸建住宅火災の特徵とし て、建物棟数が大きな要因になっていると考えられる.

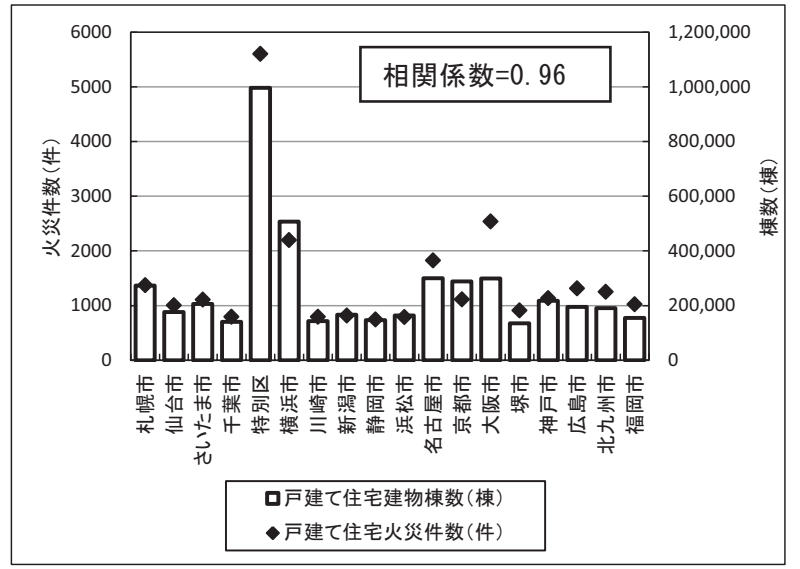

図 11 戸建て住宅火災件数と戸建て住宅建物棟数 (1998年-2008 年)

\section{2 戸建て住宅の延焼火災の割合}

次に, 各都市の延焼火災状況を得るため, 延焼火災の件数及び 1 棟火災の件数と割合を示していく.

図 12 は，政令指定都市及び東京 23 区の戸建て住宅から出火した 火災が延焼火災に発展したか，または，1 棟火災であったのかを火 災件数と割合で示したものである. 図 12 より, 多くの都市は延焼火 災件数の割合は戸建て住宅火災のうち $20 \%$ 前後である。ただし，札 幌市に関して延焼火災件数の割合が低く，10\%程度の割合である.

一方，北九州市は延焼火災件数の割合が高く $40 \%$ を超えている．札 幌市は防火造が多く，戸建て住宅の $91.2 \% （ 249,220$ 棟）を占めて おり，木造は $5.8 \%$ （15,870 棟）なので，延焼火災に発展しづらい と考えられる。一方，北九州市は，木造が 60.4\%（115,080 棟）を 占めており対象地域の中では一番多い割合である。また，防火造は $30.5 \%$ (58,080 棟) であり, 防火造の占める割合は比較的小さい都 市である，よって，木造の少ない札幌市は延焼火災件数の割合が低 
く, 木造の多い北九州市は延焼火災件数の割合が高くなったと考え られる。

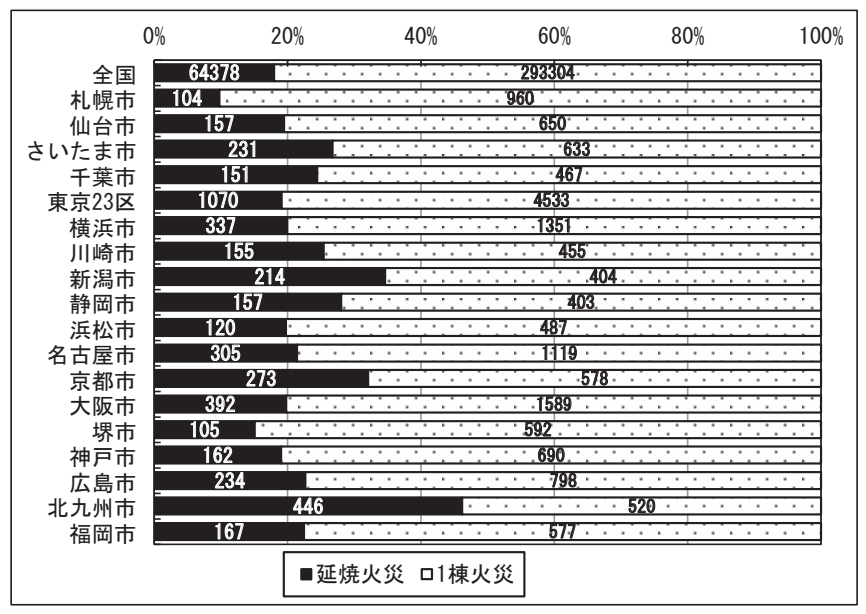

図 12 戸建て住宅が火元の延焼火災と 1 棟火災の割合

(1998 年-2008 年)

また, 図 12 の延焼火災であっても, 被延焼建物の焼損床面積が 0 $\mathrm{m}^{2}$ である軽微な火災（ぼや）が含まれている. 被延焼建物の焼損床 面積が $0 \mathrm{~m}^{2}$ であるということは, 被延焼建物の焼損が立体的に延焼 しなかった場合と, 立体的に焼損したが被延焼建物の焼損床面積が $0.5 \mathrm{~m}^{2}$ 未満（焼損床面積は四捨五入で算定される）である場合が考 えられる. そこで, 延焼火災のうち被延焼建物が立体的に延焼拡大 した, 焼損床面積が $1 \mathrm{~m}^{2}$ 以上の火災件数と $0 \mathrm{~m}^{2}$ であった火災件数に 分類し，それぞれの割合を図 13 に示す。

図 13 より，各都市間でばらつきがあり，多くの都市は概ね $20 \%$ から $40 \%$ の割合の間に被延焼建物の焼損床面積が $1 \mathrm{~m}^{2}$ 以上の火災件 数である.この図は図 12 と比べると都市間でのばらつきが大きい. このばらつきの要因は, 隣棟間隔が狭いと考えられる都市構造や火 災の発見の遅れ，消防隊の現場到着までの時間が考えられる．

図 14 は火災 1 件当たりの火元建物が戸建て住宅の焼損床面積の 期待值を示したものである. 図より, 新潟市の值が全国值より大き

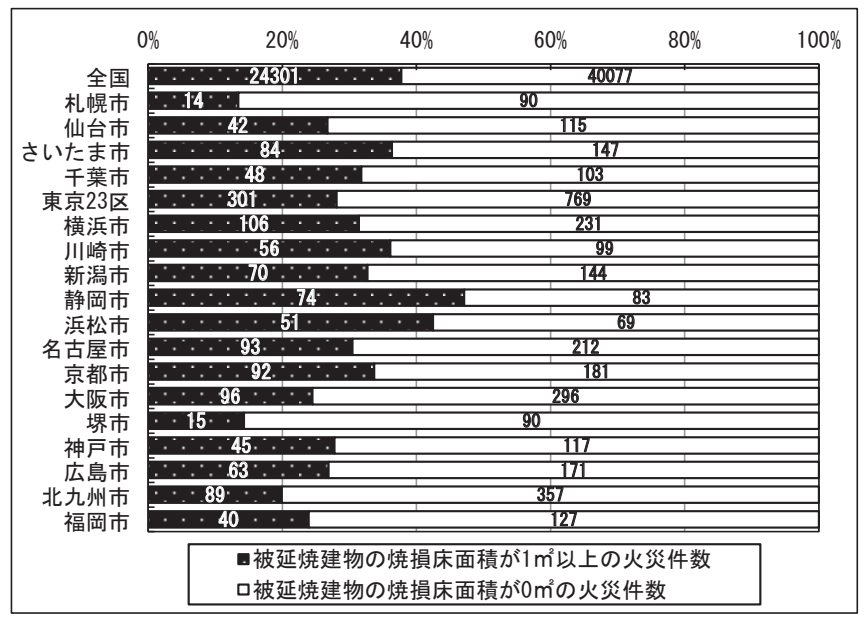

図 13 戸建て住宅が火元の被延焼建物の 焼損床面積が $1 \mathrm{~m}^{2}$ 以上の割合（1998 年-2008 年）

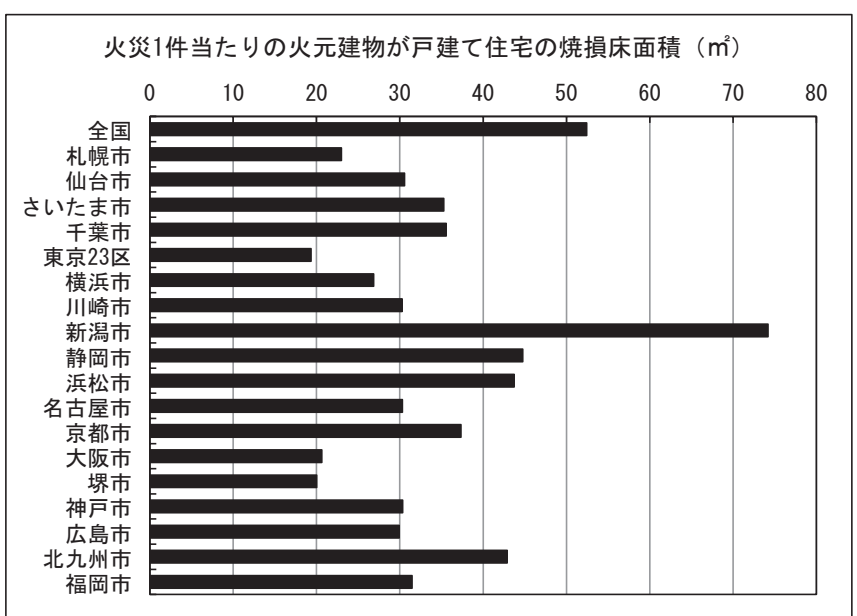

図 14 火災 1 件当たりの火元建物が戸建て住宅の 焼損床面積の期待値（1998 年-2008 年）

くなっている. 新潟市は 1 住宅当たりの延べ面積が大きいと考えら れ，住宅土地統計調查で確認したところ，全国值は $128.64 \mathrm{~m}^{2}$, 新 潟市は全国值より大きく $147.64 \mathrm{~m}^{2}$ であった.それは, 静岡市 (121.95 $\left.\mathrm{m}^{2}\right)$, 浜松市 $\left(130.11 \mathrm{~m}^{2}\right)$, 北九州市 $\left(114.87 \mathrm{~m}^{2}\right)$ の值も大きい傾 向である. 一方, 札幌市 $\left(125.86 \mathrm{~m}^{2}\right)$, 東京 23 区 $\left(108.35 \mathrm{~m}^{2}\right)$, 横 浜市 $\left(109.36 \mathrm{~m}^{2}\right)$, 大阪市 $\left(104.46 \mathrm{~m}^{2}\right)$, 堺市 $\left(114.27 \mathrm{~m}^{2}\right)$ の值は 小さい傾向である.

図 15 は火災 1 件当たりの被延焼建物の焼損床面積の期待值である. 被延焼建物の検討は図 13 でも行ったが, 都市により異なる結果とな った．まず，全国值以上の都市として，新潟市，静岡市，北九州市 がある，この要因としては，上述した通り，延べ面積が大きいと考 えられる.一方, 札幌市, 仙台市, 堺市の值が低い, 特に札幌市の 值の小ささが目立つ.これも, 上述した通り, 隣棟間隔が広く, 延 焼拡大しづらいことを示している可能性がある.

図 16 は住宅 1 棟当たりの焼損床面積の期待值である. 住宅 1 棟当 たりの焼損床面積では, 全国值より大きい都市が多数ある. 特に, ここでも新潟市の值の大きさが特徴的である．住宅 1 棟当たりの焼 損床面積で分析しても, 新潟市は規模が大きい。 また, 全国值より

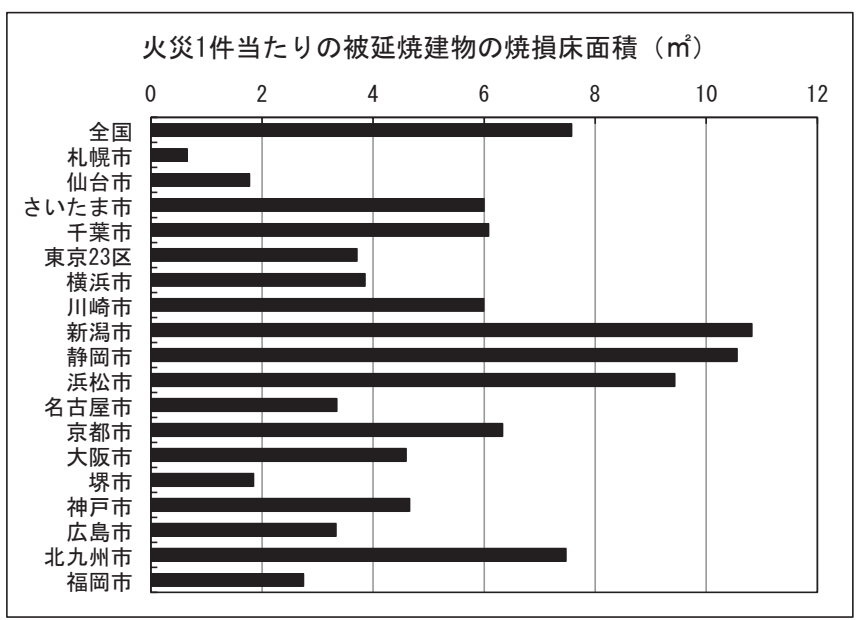

図 15 火災 1 件当たりの被延焼建物の焼損床面積の期待值 （1998 年-2008 年） 


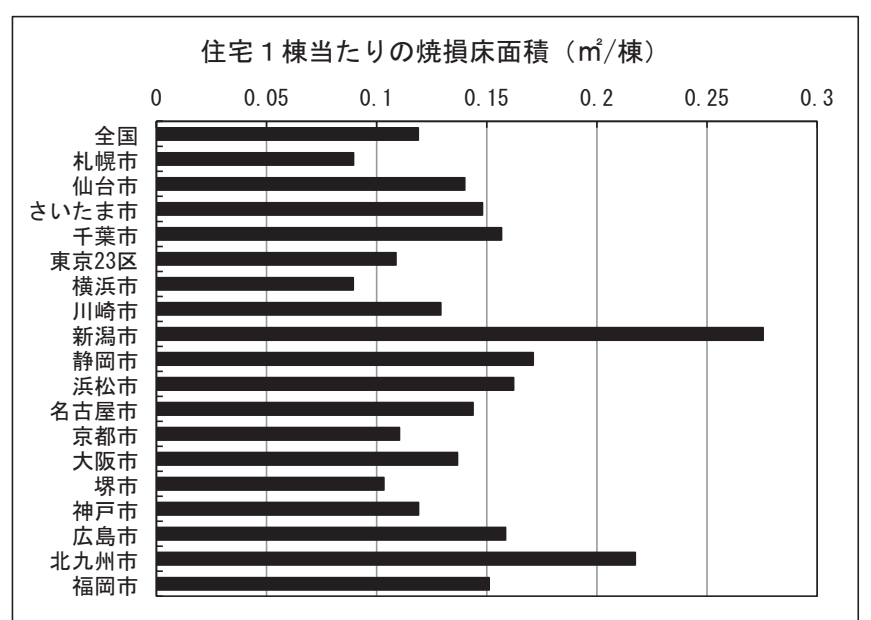

図 16 住宅 1 棟当たりの焼損床面積の期待值（1998 年-2008 年）

值が小さい都市は，札幌市，東京 23 区，横浜市，京都市，堺市であ る.これらの都市は，繁華街として発展している都市ではないだろ うか。

以上，これらより，都市別に比較する場合，今回使用している火 災統計資料では，延焼火災の性質は都市により異なる。このような 都市による違いは, 焼損床面積の計測は人間が行うものであって, 同じ都市であっても担当消防士によって差が生じる可能性がある.

\section{3 火元建物構造別火災件数之建物棟数}

延焼火災を扱うにあたり, 消防力, 被延焼建物の構造, 隣棟間距 離, 開口部の位置や構造, 外気風等が影響すると考えられるが， 1 章で記述した理由により, 本節では都市別の火元建物構造に着目寸 る.この分析を行うことで, 都市構造に関しては未検討なので, 建 物構造別に分類し, 各都市で建物構造に関しては異なるかどうかを 明らかにする目的である. さらに, 各都市の建物構造別建物棟数も 整理するので，前節で述べたように，都市間での違いも明らかにな ると考えたためである.

表 1 は, 都市別火元建物構造のそれぞれ建物構造毎の建物 1 万棟 当たりの出火件数と建物棟数を表したものである. 建物 1 万棟当た りの出火件数は, 1 棟火災, 延焼火災（被延焼建物の焼損床面積が 1 $\mathrm{m}^{2}$ 以上または被延焼建物の焼損床面積が $0 \mathrm{~m}^{2}$ ) の 3 分類である. 建 物棟数は 4.1 節での住宅・土地統計調查を利用した. ただし, 火元 建物構造を 4 区分に分類した（木造, 防火造（防火造, 準耐火（木 造)），非木造（準耐火（非木造），耐火），その他）注5).

第一に, 各割合の合計（一番右の闌）をみると，延焼火災の割合 は 1 棟火災の割合より小さく, 都市によって異なるが，概䄈 3 倍か ら 10 倍の差がある. よって, 建物 1 万棟当たりの出火件数では, 延 焼火災になる割合が小さい。ただし，新潟市と北九州市は延焼火災 の割合と 1 棟火災の割合は 2 倍以下である.これは, 先述した, 図 12 から図 16 の特徵と関係があると思われる. 特に北九州市は延焼 火災の割合が高い。このように, 表 1 から延焼火災の割合と 1 棟火 災の割合が 3 倍から 10 倍まであり,都市により異なることがみてと れる.

第二に, 延焼火災について火元建物構造別にみた場合, 防火造に 関して, 被延焼建物の焼損床面積が $0 \mathrm{~m}^{2}$ の出火件数の割合の方が大 きい，また，非木造では，どの都市においても延焼火災の割合が小
さい.

これより, 火元建物構造が防火造と非木造の建物構造は延焼しづ らい建物構造であると考えられる。

\section{4 火元建物と被延焼建物の相関}

前節までは，延焼火災と 1 棟火災の割合，被延焼建物の焼損床面 積 $1 \mathrm{~m}^{2}$ 以上と焼損床面積 $0 \mathrm{~m}^{2}$ の割合について分析をした。また，被 延焼建物に関する情報は焼損棟数々焼損床面積しかなく，焼損棟数 については 3 章で論じており，本節では被延焼建物の焼損床面積に 着目する. 火元建物の火災が被延焼建物にどの程度被害を与えてい たのかを知るため，火元建物の焼損床面積と被延焼建物の焼損床面 積が $1 \mathrm{~m}^{2}$ 以上の火災事例する焼損床面積の相関関係を考える.なお, ここでも, 火元の建物構造が被延焼建物一影響寸ると考え, 火元建 物構造を 4 区分に分類した (木造, 防火造 (防火造, 準耐火(木造)), 非木造（準耐火（非木造），耐火），その他）。

表 2 は火元建物構造別の火元建物と被延焼建物の焼損床面積の相 関を示したものである．ただし，該当セルに火災件数がない場合は 斜線「】」を記入しており，火災件数が一桁で母数が少ない場合は ハイフン「一」を記入した。 母数が少ない場合を除いた理由は，母 数が少ないことで相関係数が高くなっている可能性があり，参考に ならないためである. 火元建物が木造に関してどの都市も相関係数 が低く 0.02 から 0.27 程度である。次に，火元建物が防火造に関し て, 相関係数は 0.23 から 0.64 である. 最後に火元建物が非木造及 びその他に関しては、全体的に母数が少ない. 東京 23 区の木造及び 防火造，横浜市の木造のみが 100 件以上であるが，それ以外の項目 は母数が少なく,一番相関係数が大きい川崎市の防火造では 12 件で ある。

具体的にどのような分布形をしているのか, 分布図の一例として, 母数が一番多い東京 23 区之相関係数が一番高い（相関係数 $=0.64 ）$ 川崎市の分布を示す.

表 2 火元建物構造別の焼損床面積と 被延焼建物の焼損床面積の相関（1998 年-2008 年）

\begin{tabular}{|c|c|c|c|c|c|c|c|c|}
\hline & \multicolumn{8}{|c|}{ 火元建物構造 } \\
\hline & \multicolumn{2}{|c|}{ 木造 } & \multicolumn{2}{|c|}{ 防火造 } & \multicolumn{2}{|c|}{ 非木造 } & \multicolumn{2}{|c|}{ その他 } \\
\hline & 件数 & $\begin{array}{l}\text { 相関 } \\
\text { 係数 }\end{array}$ & 件数 & $\begin{array}{l}\text { 相関 } \\
\text { 係数 }\end{array}$ & 件数 & $\begin{array}{l}\text { 相関 } \\
\text { 係数 }\end{array}$ & 件数 & $\begin{array}{l}\text { 相関 } \\
\text { 係数 }\end{array}$ \\
\hline 札幌市 & 3 & - & 11 & 0.23 & & 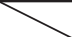 & & \\
\hline 仙台市 & 41 & 0.27 & $>$ & $x$ & $>$ & 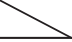 & 1 & - \\
\hline さいたま市 & 81 & 0.02 & 2 & - & 1 & - & & \\
\hline 千葉市 & 45 & -0.12 & 2 & - & 1 & - & & \\
\hline 東京23区 & 160 & 0.23 & 136 & 0.27 & 4 & - & 1 & - \\
\hline 横浜市 & 103 & 0.01 & 2 & - & & 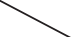 & 1 & - \\
\hline 川崎市 & 44 & 0.06 & 12 & 0.64 & & 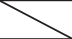 & & \\
\hline 新潟市 & 69 & 0.13 & 1 & - & $\rightarrow$ & 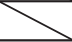 & & \\
\hline 静岡市 & 69 & 0.08 & 3 & - & 1 & - & 1 & - \\
\hline 浜松市 & 46 & -0.05 & & 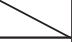 & 1 & - & 4 & - \\
\hline 名古屋市 & 90 & 0.18 & 2 & - & 1 & - & & \\
\hline 京都市 & 84 & 0.18 & 5 & - & 1 & - & 2 & - \\
\hline 大阪市 & 50 & 0.04 & 41 & 0.30 & 4 & - & 1 & - \\
\hline 堺市 & 7 & - & 7 & - & 1 & - & & \\
\hline 神戸市 & 35 & 0.27 & 7 & - & 2 & - & 1 & - \\
\hline 広島市 & 37 & -0.03 & 25 & 0.60 & 1 & - & & \\
\hline 北九州市 & 88 & 0.21 & 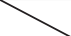 & 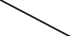 & 1 & - & & \\
\hline 福岡市 & 34 & -0.22 & 6 & - & & & & \\
\hline
\end{tabular}


表 1 都市別火元建物構造の建物 1 万棟当たりの出火件数と建物棟数（1998 年-2008 年）

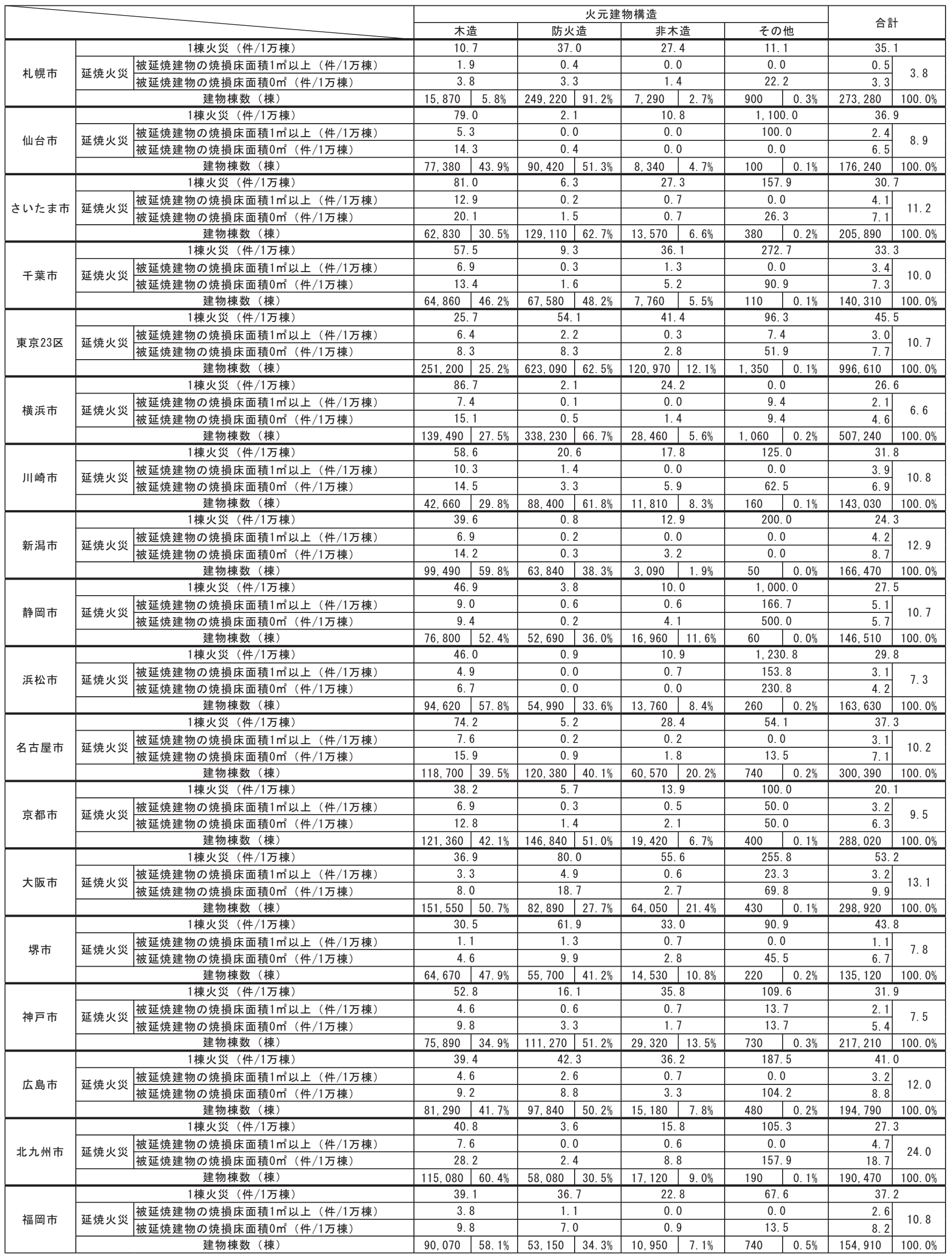




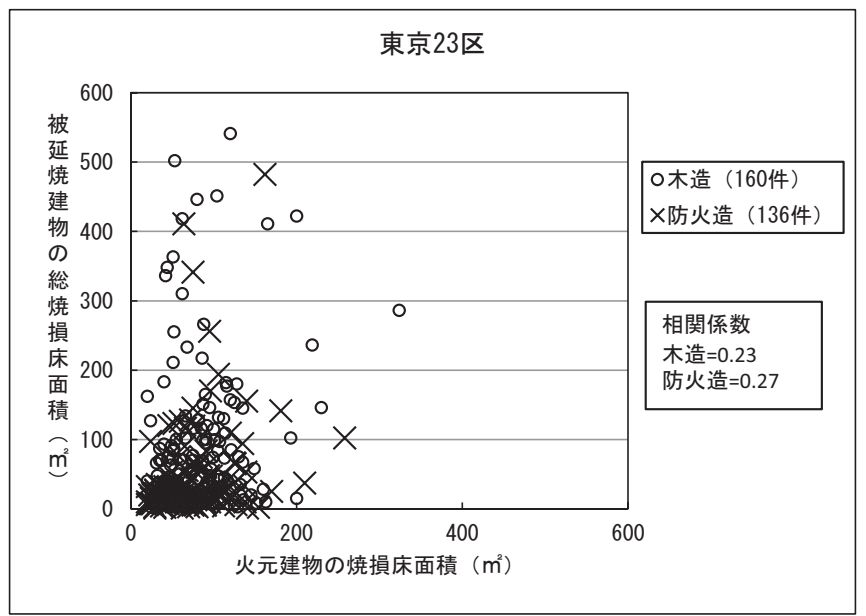

図 17 東京 23 区の分布図（1998 年-2008 年）

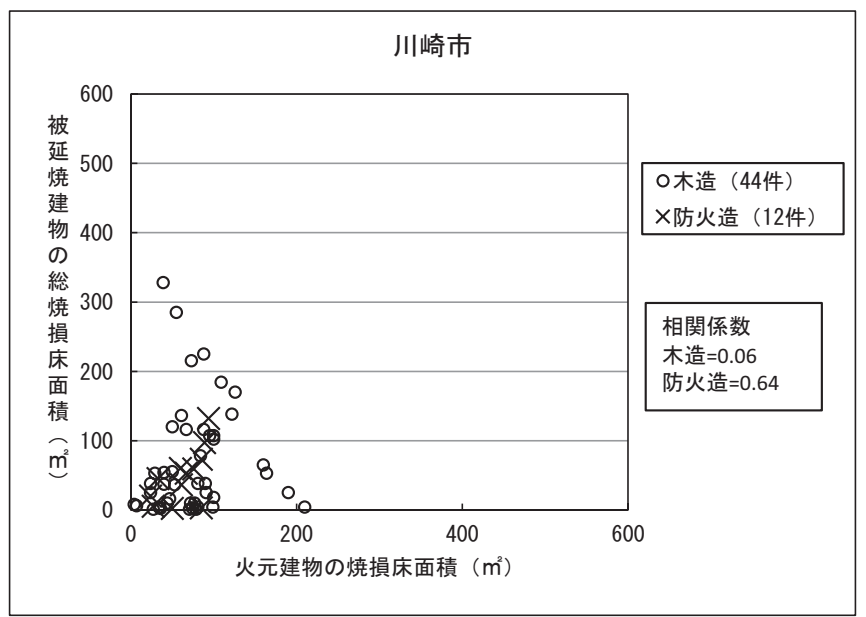

図 18 川崎市の分布図（1998 年-2008 年）

図 17 より，木造の相関係数は 0.23 , 防火造の相関係数は 0.27 で あり，全体的に分布している.

図 18 より,木造の相関係数は 0.06 , 防火造の相関係数は 0.64 で あり, 防火造に正の相関がみられる. 木造は 2 つのグループに分け られる. 1 つは火元建物の焼損床面積及び被延焼建物の総焼損床面 積が共に小さい部分に分布しているグループである.もう1つは火 元建物の焼損床面積が小さい時に被延焼建物の総焼損床面積が大き くなり, 火元建物の焼損床面積が大きい時に被延焼建物の総焼損床 面積が小さくなる負の相関を表しているグループである．ただし，

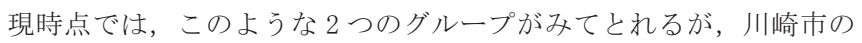
母数がまだ少なく（44 件), 母数が東京 23 区程度（160 件）に増え れば，現在の分布とは異なる分布をする可能性はある。よって，今 後とも追跡調査をする必要があると考える。

これらから, 火元建物の焼損床面積と被延焼建物の総焼損床面積 の観点では相関係数が低く独立した事象であると考えられ，隣棟間 隔や被延焼建物の建物構造にも依存している可能性がある.

\section{5. まとめ}

本稿は，火災統計資料に基づき，延燒火災について火災件数と焼 損床面積を指標に分析を行った。 以下に分析により得られた結果を
記述する。

まず，全国の火災については以下の通りである.

- 出火月に関して，全ての建物火災の火災件数と延焼火災のみの火 災件数には強い相関がある.

- 延焼火災発生の時間については, 特徵的な事柄を示した。特に, 深夜の放火，放火の疑いからの延焼拡大の可能性は特筆す心゙き事項 である。

・建物用途別の延焼火災件数及び焼損床面積では, 戸建て住宅が 1 位である。

・ 火元建物が戸建て住宅からの火災の総焼損床面積の各棟数別では, 戸建て住宅火災件数は多いが，火災の規模は大きくない，

- 火元建物が戸建て住宅からの火災の被延焼建物の焼損床面積の累 積度数分布より，焼損床面積 $0 \mathrm{~m}^{2}$ の割合が大きい.

次に, 政令指定都市及び東京 23 区の火元が戸建て住宅からの火 災は以下の通りである。

・火災件数と建物棟数は強い相関がある.

- 図 12 から図 16 より, 都市別に延焼火災を比較する場合, 今回使 用寸る火災統計資料では，都市によって異なる，特に特徵的な都市 は札幌市，新潟市，北九州市である.

・ 火元建物構造では, 防火造と非木造の建物は延焼しづらい.

- 火元建物の焼損床面積と被延焼建物の焼損床面積は相関関係が低 い.

以上，本稿は，延焼火災における出火時間に関して，推測の考察 であったが，要因を探り，延焼火災件数減少に貢献できる可能性が ある。また，火元建物構造が防火造か非木造であると延焼しづらい 建物構造といえるだろう。都市別の分析より，各都市の違いを明ら かにすることができれば，都市の延焼防止の政策に貢献できると考 える。

最後に, 本研究は戸建て住宅を含め各建物用途が何棟焼損したの かを知る必要があると考えている。しかし，現在の行政から得られ るデータからでは，火元建物は特定できるものの，延焼を受けた建 物の特性が記述されていないため, 延焼を受けた建物用途別の数を 知ることができない，また，被延焼建物の構造，火元建物との隣棟 距離，開口部の位置や構造も記述されていない。これは，今後の課 題として，行政に期待する.

\section{謝辞}

本研究にあたって, 辻本誠教授, 西田幸夫講師, 小林恭一教授に ご指導頂きました，焼損床面積及び焼損表面積について関澤愛教授 にご教示頂きました。また，論文審查員の方々には，本論文を良く するために貴重なご意見を頂きました。ここに謝意を表します.

\section{参考文献}

1) 平成 21 年版 消防白書 : http://www.fdma.go.jp/html/hakusho/h21/index. $\mathrm{html}$ (2011 年 2 月 10 日参照)

2)関沢愛, 堀内三郎 : 焼損面積の算定要領についての問題, 日本火災学会, 火災 27 (1) , pp. 42-46, 1977.2

3) 佐藤博臣, 村井裕樹, 志田弘二, 栗岡均: 火災統計データに基づく火災拡大危 険度評価法, 日本建築学会環境系論文集, 第 605 号, pp. 1-8, 2006. 7

4) 佐藤博臣, 志田弘二, 栗岡均, 村井裕樹 : 住宅における焼損床面積分布の火災 統計分析, 日本建築学会環境系論文集, 第 614 号, pp. 9-16, 2007.4 5) 野崎洋之, 小林裕 : 統計データに基づく火災リスク評価手法について一（そ 
の 1）火災リスク評価手法の全体構成と火災の発生確率一, 日本火災学会, 日本火災学会研究発表会梗概, pp. 350-351, 2004. 5

6) 小林裕, 野崎洋之: 統計データに基づく火災リスク評価手法について一（そ の 2) 火災リスク曲線の定式化法の提案一, 日本火災学会, 日本火災学会研 究発表会梗概集, pp. 352-353, 2004.5

7) 亀井幸次郎: 延焼火災実数と大火実数との関係, 日本建築学会論文報告集, 第 60 号, pp. 521-524，1958.10

8) 横井鎭男：火災統計からみた府県別延焼危険度，日本建築學會研究報告， 第 4 号, pp. 526-527, 1949.11

9) 塚越功, 系井川栄一：延焼遮断帯に対する火災外力の想定一都市防火区画 の計画における延焼遮断帯の評価に関する研究 その 1 -, 日本建築学会 論文報告集，第 340 号，pp. 92-100，1984.6

10) 村田明子: 兵庫県南部地震の被害と地域特性の関連, 地域安全学会論文報 告集 (5)，pp. 13-20，1995.11

11) 高井宏行, 矢野公一, 松井武史, 坊池道昭, 上村雄二 : 神戸市における地 震火災の発生と延焼動態に関する研究, 日本建築学会計画系論文集, 第 508 号, pp. $137-144$, 1998.6

12) 加藤孝明, 小出治: 市街地延焼からみた市街地整備のための性能基準に関 する基礎的考察一不燃領域率による性能基準の一般化一, 日本建築学会計 画系論文集，第 516 号，pp. 185-191，1999.2

13) 加藤孝明, 久貝壽之, 小出治, 南部世紀夫, 出原至道: 市街地延焼からみ た市街地整備のための性能基準に関する基礎的考察（その 2) 一有限領域 への展開一, 日本建築学会計画系論文集, 第 525 号, pp. 241-248, 1999. 11

14) 齋藤正俊, 熊谷良雄, 系井川栄一: 火災延焼からみた木造密集市街地改善 プログラムの評価手法とその適用性に関する研究, 地域安全学会論文報告 集 No. 1，pp. 57-62，1999.11

15) 加藤孝明, 久貝壽之, 小出治, 南部世紀夫 : 市街地延焼からみた市街地整 備のための性能基準に関する基礎的考察（その3）－建物配置の現実化『逐 次充填間引き分布』についての考察一, 日本建築学会計画系論文集, 第 534 号, pp. $163-170,2000.8$

16) 村田明子, 横田英邦, 北後明彦, 室崎益輝: 兵庫県南部地震時に出火した 耐火造・準耐火造からの延焼要因, 日本建築学会計画系論文集, 第 553 号, pp. $1-8,2002.3$

17) 木村雄介, 系井川栄一: 市街地における延焼危険度の増加要因に関する研 究, 地域安全学会論文報告集 No. 10, pp. 21-29, 2008.11

18) 伊藤甫: 火災延焼期待值の研究, 日本建築學會論文集, 第 36 號, pp. 65-69, 1947. 12

19) 田村一彦, 西形國夫, 中村勇人, 阿出川悟 : 延焼シミュレーションによる 市街地大火の延焼拡大予測, 地域安全学会論文報告集 (3), pp. 293-299, 1993.5

20)鈴木圭一, 吉田治典: 火災リスク評価のための確率論的な延焼拡大モデル を用いた火災シミュレーション, 日本建築学会環境系論文集, 第 567 号, pp. $15-19,2003.5$

21) 出口嘉一, 河野守, 辻本誠, 五頭辰紀 : 可燃物配置の不規則性を考慮した 実験にもとづく火災延焼モデル, 日本建築学会環境系論文集, 第 594 号, pp. $1-6,2005.8$

22) 樋本圭佑, 田中哮義: 都市火災の物理的延焼性状予測モデルの開発, 日本 建築学会環境系論文集，第 607 号，pp. 15-22，2006.9

23) 飯塚裕介, 青木義次: 状態遷移確率モデルを用いた延焼危険度の変化傾向 の分析, 日本建築学会計画系論文集, 第 612 号, pp. 93-98, 2007.2

24) 西野智研, 円谷信一, 樋本圭佑, 田中㨍義: 準定常的な計算法を用いた都 市火㷋延燒性状の簡易予測モデルの開発一地震火㷋時の都市住民避難性状 の推定に関する研究一, 日本建築学会環境系論文集, 第 75 巻, 第 647 号, pp. $9-18,2010.1$

25) 保野健治郎, 高井宏行, 難波義郎：建物火災の延焼に関する基䃈的研究, 日本火苂学会論文報告集，Vol. 32，No. 1，pp. 23-32，1982

26) 保野健治郎, 高井宏行, 難波義郎：ロジスティック曲線による建物火災の 延焼速度式に関する基礎的研究, 日本建築学会論文報告集, 第 311 号, pp. 137-143, 1982. 1

27) 保野健治郎, 高井宏行, 難波義郎, 遠木律夫 : 定差図法に上る建物火災の 延焼速度式（ロジスティック曲線）に関する基礎的研究，日本建築学会論 文報告集，第 325 号，pp. 155-163，1984.3

28) 保野健治郎, 難波義郎, 西谷忠彦: 地震時市街地火災の延焼速度式と予測 に関する基礎的研究, 日本建築学会計画系論文集, 第 501 号, pp. 9-15, 1997. 11

29) 難波義郎, 保野健治郎: 地震時市街地火災の延焼速度に関する基礎的研究,
日本建築学会計画系論文集，第 520 号，pp. 1-7, 1999.6 30)総務省消防庁，火災報告，総務省消防庁，1995 年 -2008 年 31) 総務省統計局 : 平成 15 年住宅・土地統計調查,

http://www.stat.go.jp/data/jyutaku/2003/index. html（2011 年 2 月 10 日参照）

注

注 1)既往の研究では, 焼損床面積及び焼損表面積の定義が示されておらず, また，その算定方法が独特なので本稿でこれらの定義を示す，新火災調査 技術教本（財団法人 東京防災指導協会: 新火琰調查技術教本, 東京法令 出版株式会社，1998．7）によると，焼損床面積とは，「建物の焼損が立体 的に及んだ場合に，建物としての機能が失われた部分について，その部分 の水平投影面積で算定する」であり, 焼損表面積とは, 「建物の焼損が平面 的で，立体的でない場合に焼損部分を表面積で算定する」と定義されてい る.

注 2) 火災報告とは, 火災報告取扱要領ハンドブック（防災行政研究会：火災 報告取扱要領ハンドブック，東京法令出版株式会社，2006. 2) の第 1 号様 式（その 1) 及び（その 2) を指す，火災報告の入手方法は総務省消防庁に 行政文書開示請求をすることにより電子データを得ることができる，火災 報告の取扱については, 1994 年 4 月 21 日付けで消防長官から各都道府県 知事に通知され 1995 年 1 月 1 日の火災から電子データ化が実施された. 消 防白書は，火災報告を基に作成されている．

注 3) 1995 年のデータについて, 兵庫県南部地震の影響があると考え, 1995 年のデータを除き,また, 東京 23 区に関して, 1995 年から 1997 年まで (延 焼火災件数が全体の約 96\%）の3 年間と 1998 年以降（延焼火災件数が全 体の約 10\%）では，延焼火琰件数の割合が不自然であった，そこで，東京 23 区に関して, 1995 年から 1997 年までの 3 年間の延焼火災のデータを除 く.さらに, 東京 23 区の火災件数が全体に影響を及ぼすので, 本稿では全 国の 1995 年から 1997 年までの 3 年間を除く.

注 4) 防災行政研究会「火災報告取扱要領ハンドブック」に基づいて分類して いる.

注 5) 建物構造の分類は建築基準法に準抛する。「その他」とは, 木造から耐 火構造までに掲げる建築物以外のものをいう.

(2011年 4 月 7 日原稿受理，2011年10月12日採用決定) 